\title{
$9-2011$
}

\section{Religiosity, Delinquency, and the Deterrent Effects of Informal Sanctions}

Andrew L. Spivak

University of Nevada, Las Vegas

Miyuki Fukushima

Cleveland State University, m.fukushima@csuohio.edu

Margaret S. Kelley

University of Illinois at Urbana-Champaign, mskelley@illinois.edu

Tiffany Sanford Jenson

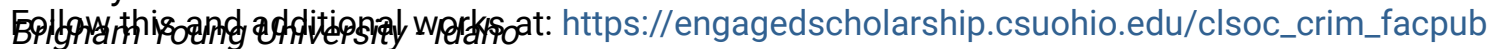

Part of the Educational Sociology Commons, and the Social Control, Law, Crime, and Deviance Commons

How does access to this work benefit you? Let us know!

\section{Publisher's Statement}

This is an Accepted Manuscript of an article published by Taylor \& Francis in Deviant Behavior on September, 2011, available online: http://wwww.tandfonline.com/10.1080/ 01639625.2010 .514211$.

\section{Repository Citation}

Spivak, Andrew L.; Fukushima, Miyuki; Kelley, Margaret S.; and Jenson, Tiffany Sanford, "Religiosity, Delinquency, and the Deterrent Effects of Informal Sanctions" (2011). Sociology \& Criminology Faculty Publications. 103.

https://engagedscholarship.csuohio.edu/clsoc_crim_facpub/103

This Article is brought to you for free and open access by the Sociology \& Criminology Department at EngagedScholarship@CSU. It has been accepted for inclusion in Sociology \& Criminology Faculty Publications by an authorized administrator of EngagedScholarship@CSU. For more information, please contact library.es@csuohio.edu. 


\title{
religiosity, delinquency, and the deterrent effects of informal sanctions
}

\author{
Andrew L. Spivak
}

University of Nevada Las Vegas, Las Vegas,

Nevada, USA

\section{Miyuki Fukushima}

Cleveland State University, Cleveland, Ohio, USA

\section{Margaret S. Kelley}

University of Illinois at Urbana-Champaign, Urbana, Illinois, USA

\section{Tiffany Sanford Jenson}

Brigham Young University_Idaho, Rexburg, Idaho, USA

Past research in deterrence theory suggests that informal social sanctions intervene in the effect of religiosity on criminal and delinquent behavior, such that more religious individuals tend to perceive stronger informal sanctions (Grasmick, Bursik and Cochran 1991a; Grasmick, Kinsey and Cochran 1991b). This study examines the influence

The authors gratefully thank Mary Outwater for managing the data collection. We also thank Susan F. Sharp for guidance and helpful suggestions in the development of the article, as well as Harold G. Grasmick for expertise and insight on key theoretical and methodological issues.

Address correspondence to Andrew L. Spivak, Ph.D., Assistant Professor, Department of Sociology, University of Nevada Las Vegas, 4505 Maryland Parkway, Box 455033, Las Vegas, NV 89154-5033, USA. E-mail: andrew.spivak@unlv.edu 
of religiosity and social deterrence on college students' delinquent behavior, as measured by anticipated violation of a university's alcohol policy. Data were collected through a survey of undergraduate students $(n=484)$ at a large South-Midwestern public university that instituted a campus alcohol ban. The survey took place three months after the ban was implemented and asked students about religiosity, perceptions of informal deterrence, and expectations of violating the policy. Results partially support the hypothesis that religiosity predicts conformity primarily through the deterrent threat of informal sanctions. Religiosity increased perceived threats of shame and embarrassment, which in turn reduced the likelihood of anticipated policy violation. When controlling for demographics, college lifestyle, attitudes, and past drinking behavior, shame remained a significant predictor of expected policy violation, but embarrassment did not. Also, contrary to expectations, one measure of fundamentalist religiosity (biblical literalness) retained a direct main effect on intended compliance, even when taking informal sanctions into account. Theoretical, methodological, and policy implications are discussed.

\section{INTRODUCTION}

The primary objective of the this study is to contribute to efforts in understanding the relationship between religiosity and conformity by considering the deterrent effects of informal sanctions. This research is timely and unique in that the data collection was conducted within three months of the implementation of a campus alcohol ban. The ban was instituted in response to several high profile alcohol-related incidents, including one that resulted in the death of an underage fraternity student following extremely heavy drinking, prompting an outcry among parents for regulations limiting students' alcohol use. The stated goals of the new policy were to curtail underage drinking and drunk driving, as well as to address the risks present at on-campus parties where alcohol is served. 


\section{Deterrence and Social Sanctions}

Deterrence theory follows the tradition of rational choice and utilitarian perspectives in the classical school of criminology (Beccaria [1775] 1963; Bentham [1789] 1970). The rational choice perspective is based on the premise that humans are profit maximizers, seeking the greatest reward at the lowest cost, and thus behaviors are the result of a calculation of possible costs and benefits; the likelihood of engaging in an action increases when the probable benefits exceed the costs (Geerken and Gove 1975). Central to the cost/benefit calculation is the premise that human behaviors reflect perceived or anticipated fear of negative consequences, and deviant behaviors are more likely to be avoided when the fear of negative consequences is high (Tittle and Paternoster 2000). These behavioral mechanisms coincide with the popular and commonsensical idea that the threat of sanctions deters criminal and delinquent activity. The principles of deterrence thus form the basis for our system of criminal justice and for formal sanctioning policies within many social institutions (schools, religious organizations, military services), and have been of substantial interest to researchers and lawmakers over the past several decades (Akers 1990; Pratt, Cullen, Blevins, Diagle, and Madensen 2006).

Early studies on deterrence were primarily concerned with the macro level effects of official sanctions in the criminal justice system (Zimring and Hawkins 1973; Gibbs 1975). However, the precise mechanisms that explain deterrence were not well understood and did not provide consistent results. While subsequent research has not definitively confirmed the proposition that fear of punishment is sufficient to prevent the commission of crime (Paternoster 1987; Bohm 1997), two consistent findings have been that "punishment certainty is far more consistently found to deter crime than is punishment severity, and the extralegal consequences of crime seem at least as great a deterrent as do the legal consequences" (Nagin and Pogarsky 2001:865).

Informal sanctions, such as the negative consequences deriving from reactions of others close to the individual, appear to have a stronger deterrent effect on individuals than formal sanctions (Foglia 1997; Tittle and Paternoster 2000). Informal sanctions may be perceived to have more certainty 
because an individual will be less able to hide deviant behavior from someone close to them, even if they could disguise it from a much larger formal authority.

Grasmick, Bursik and Arneklev (1999) suggest that shame and embarrassment comprise two such types of informal sanctions. They conceptualize shame as "a self-imposed sanction, occurring when actors violate norms they have internalized" (43). In contrast, embarrassment or "stigma" is defined as "a socially imposed sanction that occurs when actors violate norms endorsed by others whose opinions the actors value and who become aware of the actor's transgressions" (43-44). Thus, shame feels like guilt or remorse, while embarrassment feels like loss of respect.

Our work fits into the school of criminological research that attempts to explain projected offending (Nagin and Pogarsky 2003; Pogarsky 2004) and perceptual deterrence (Lanza-Kaduce 1988; Klepper and Nagin 1989). Since people are often unaware of the actual levels of certainty and severity of consequent sanction, deterrence theory is frequently tested by examining subjective perceptions of punishment (Liska and Messner 1999). Similarly, we examine the perceived social sanctions of violating a new alcohol policy by measuring students' projected offending, or anticipation of violating the official university policy.

\section{Religiosity and Deterrence}

Despite religion's important historical role in dealing with crime and punishment (Garland 1990), it has not received as much attention as other social phenomena in the study of crime, largely due to the dominance of secularization and its focus on modernizing processes, including a decline in the importance of religion (Grasmick, Davenport, Chamlin and Bursik 1992). Revived attention to religion in criminology occurred, however, when Hirschi and Stark (1969) published surprising results showing a lack of relationship between delinquency and frequency of church attendance. Since the publication of that study, researchers have examined the effects of varying aspects of religion on measures of deviance and criminality, dissecting the concept of religion and religiosity to include not only frequency of attendance, but salience (perceived importance), specific beliefs, and even categorizations of common Christian denominations 
(Grasmick et al. 1991b). Studies subsequent to Hirschi and Stark (1969), therefore, produce inconsistent evidence for the effect of religion on deviance (Tittle and Welch 1983), and in recent years attention has shifted to the examination of "the conditions under which religiosity might have an effect on compliance with the law" (Grasmick et al. 1991a:251).

For example, one study found that religiosity constrains deviant behavior more strongly in an environment that is characterized by high social disorganization and norm ambiguity or weak secular controls (Tittle and Welch 1983). Similarly, another study revealed that religious participation has a much stronger constraining effect on ascetic behaviors such as alcohol and marijuana use than on property crimes and violent offenses (Burkett and White 1974). Both of these results implicate a stronger influence of religion on constraining deviant behavior when such behavior is against religious asceticism, but at the same time not as strongly condemned in mainstream society as violent and property offenses (Cochran 1988). In other words, where secular moral guidance is absent or ambiguous (as in the case of ascetic behaviors), religious moral guidance might play a more important role (Grasmick et al. 1991a). For this reason, we may expect to find less significant effects of religion on deviant behaviors that are clearly and strongly condemned in society, including many crimes and delinquencies. The idea of strong societal condemnation encompasses and is affected by both perceived social harm as well as perceptions of deliberate victimization, such as murder, rape, robbery, and so on... which are both harmful and conducted with malicious intent. Behaviors that are clearly condemned in modern, mainstream secular society have less need for religion to provide further reinforcement (Burkett and Ward 1993), while behaviors like alcohol and marijuana use may be perceived as less deserving of such direct condemnation because they do not involve the overt victimization of nonparticipants through acts of force or fraud.

Thus, religion might work as a stronger deterrent against deviant behaviors for which moral ambiguity is greater, especially for anti-ascetic behavior, like alcohol consumption (Middleton and Putney 1962). In the United States, although alcohol has historically been seen as a social ill 
and a cause of social problems, it is nonetheless deeply embedded in social life, as noted by Inciardi (2002:69), who calls it "the all-time favorite intoxicant for millennia," which generates the "constant tension between guilt and pleasure, morality and control" (Workman 2001:137). We should thus expect to find a stronger deterrent effect of religion against drinking, compared to the effect of religion as a deterrent against other, more clearly condemned behaviors, such as murder.

Furthermore, Grasmick and colleagues (1991a) found that religion works as a deterrent to deviant behavior by increasing the informal sanctions against such behavior. According to Grasmick and Green (1981a), religion often leads to avoiding deviance out of a strong desire to do right, rather than avoiding the consequences of wrongdoing (i.e., formal sanctions). Criminal activity will be less likely among persons who are strongly committed to norms that require a moral selfconcept. For very religious individuals, moral commitment may have a stronger influence than will external sanctions, particularly for behaviors against which they have strong moral convictions. Therefore, moral commitment presents an inverse relationship with the impact of formal sanctions; the higher a person's moral commitment, the less likely that formal sanctions will provide a deterrent impact, as internalized morality replaces the threat of a formal, external sanction (Grasmick and Green 1981a). In the framework of classical functional theory in sociology, a formal sanction merely provides secondary support for moral authority, reminding a person of the sanctity of the norm, and thus the primary source of social control lies in the threat of informal, social sanctions (Durkheim [1912] 1947; Grasmick and Green 1981b).

\section{College Drinking as Delinquency}

Drinking is often considered a rite of passage into college life and plays a central role in the college experience (Straus and Shelden 1953; Workman 2001). Bars surrounding college campuses tend to carry cheaper beer and liquor shots while alcohol companies often target college-aged young adults in their advertising (Inciardi 2002; Kuo et al. 2003).

Binge drinking, also known as heavy episodic drinking, is commonly defined in research as the consumption of five or more drinks at a single occasion (Wechsler et al. 2000; 
Inciardi 2002; Lange et al. 2002). Since the publication of a well-known study of binge drinking among college students (Wechsler et al. 1993; Wechsler et al. 1998) and subsequent attention generated within the American Medical Association, drinking as a public health threat on campus has captured increasing attention in recent years (Chaloupka and Weschler 1996; Williams et al. 2005). Binge drinking is recognized as having complex causes and as causing many individual and social problems (Chaloupka and Weschler 1996; Donovan et al. 1999; Burden and Maisto 2000; Wechsler et al. 2000; Lange et al. 2002; Wolaver 2002; Clapp et al. 2003; Weitzman and Nelson 2004; Clapp et al. 2005). Students who profess a "life as a party" mentality toward college life are those most likely to experience problems with drinking (Shover and Honaker 1992). Currently, almost every university in the United States provides some kind of alcohol intervention/prevention program for students (Inciardi 2002). Some campuses focus on controlling consumption through dry policies and coinciding punishments designed to curb drinking behaviors, while other schools implement a wet policy, which provides a controlled environment for students to learn to drink responsibly (Workman 2001). However, the available evidence on the effectiveness of alcohol regulations, whether based on dry or wet policies, is inconclusive (Workman 2001).

The Harvard College Alcohol Study revealed that the availability of alcohol education programs for college students increased considerably between 1993 and 2001. Additionally, more than half of the students surveyed during this period received information about institutional rules regarding possession and consumption of alcohol, policies about enforcement, and services to provide assistance with problem drinking issues (Wechsler et al. 2002).

Drinking regulation policies on college campuses often focuses on restricting the supply of alcohol, the demand, or both, but those policies geared toward limiting demand are typically less inclined to ban alcohol entirely (Wechsler et al. 2004). Nonetheless, full campus-wide bans do show some level of empirical support. The prevalence of drinking, as well as heavy episodic drinking, is lower at institutions that limit students' ability to obtain alcohol by banning it on campus (Wechsler et al. 2001). 
Some research has also identified unintended consequences of campus-wide bans on alcohol use. Wechsler and colleagues found that alcohol bans could result in a polarization of drinking behaviors; instead of an overall reduction in problem drinking, some students abstain while other moderate drinkers cross over into problem drinking (Wechsler et al. 2002). Other studies have noted that the success of campus alcohol bans is strongly influenced by the availability of drinking outlets off-campus. One study revealed that when colleges ban drinking on campus, a high density of alcohol outlets had a positive and significant effect on the odds of students' moving from abstention to moderate drinking, and from moderate to heavy drinking (Williams et al. 2005). Also, students' level of consensus about the development of bans appears to influence the success of such policies (Mills et al. 1981). When students perceive the policy as legitimate and the sanctions as consequential, the ban is more likely to be effective (Mooney and Gramling 1993). However, students' level of knowledge about the specific provisions of an alcohol policy has been found to be unrelated to their likelihood of compliance (Kelley et al. 2009). Finally, other research generally suggests that individually tailored intervention/prevention policies or programs might be more effective than broad abstinence policies (Clapp et al. 2003, 2005; Wagenaar et al. 2005).

The new alcohol policy under investigation in this project took effect on the first day of the spring semester. Concerns with alcohol problems on campus and the need for a new alcohol policy had been present for some time; however, an alcohol incident resulting in the death of an underage fraternity student expedited the process. Soon after the death, the president of the university called for the convening of a task force committee. The committee was composed primarily of university administrators along with a few faculty and several student representatives.

The primary change implemented by the new policy is the creation of a virtually dry campus. Sororities, because of national rules, were already dry, as were the residential halls, but the dry policy was extended to fraternities, and campus owned buildings and surrounding property. However, alcohol is still allowed at three university-owned apartment complexes, at tailgating parties for sporting events on university 
property, and at any other on-campus facility that has a icense to provide alcohol. Furthermore, campus-affiliated student organizations, including fraternities and sororities, can still host weekend events that serve alcohol with advance permission. These campus-approved events, however, cannot be held on sorority or fraternity property.

\section{Hypotheses}

Our first hypothesis is that (1) informal sanctions of shame and embarrassment will be negatively related to anticipated policy violation. This hypothesis reflects the influence of informal social sanctions on conformity (Foglia 1997; Tittle \& Paternoster 2000, Grasmick et al. 1999). Students who are more likely to expect negative social and internal consequences will be more likely to avoid violating the policy.

Our second hypothesis is that (2) measures of religiosity will be negatively related to anticipated policy violations, and this negative relationship will be stronger for the fundamentalist measures of religiosity (see methods, next section) than for salience. In this case, behaviors that are not widely condemned in larger society, but which tend to be ascetically proscribed, will be negatively related to religiosity (Tittle \& Welch 1983, Burkett \& White 1974, Cochran 1988). For those students who score higher on fundamentalist measures of religiosity, this relationship should be more pronounced, reflecting stronger prohibitions against drinking (Grasmick et al., 1991b).

Furthermore, we predict that (3) measures of religiosity will be positively related to informal sanctions of shame and embarrassment. Both the likelihood of feeling guilty (shame) and the likelihood of sensing social disapproval (embarrassment) will be stronger for more religious students (Grasmick and Green 1981a; Grasmick et al. 1991a).

Our last hypothesis is that (4) when considered together, informal deterrence measures will continue to show a direct effect on anticipated violation, while the relationship between religiosity and anticipated violation will be reduced below significance, demonstrating that religiosity's effect on policy compliance is indirect. In accordance with Tittle and Welch (1983) and Grasmick et al. (1991a), the conforming effect of religion is indirect; religion fosters normative attachments with conventional associates and internal values that 
will deter the anticipation of disapproved behavior by threats of shame and embarrassment.

\section{METHODS}

Data used to test the hypotheses were obtained from a large South-Midwestern state university in the spring of 2005, with a total enrollment of approximately 23,000 during that semester. This university is within a large metropolitan area that includes the state capital, with a total population of just over one million. In order to make the sample representative of those who would most likely be affected by the new alcohol policy, we selected only full-time undergraduate students between the ages of 18 to 26 .

After obtaining approval from the Institutional Review Board, we contracted the university's polling laboratory to conduct the survey by telephone shortly after spring break; interviews lasted about 12 minutes each. Complete data were obtained from a total of 503 students and an additional 14 interviews were partially completed for an overall $50.0 \%$ response rate. For the population of interest, the $503 \mathrm{com}-$ plete interviews represent a margin of error of $+/-4.3 \%$ at the $95 \%$ confidence level. An additional 19 respondents were removed from the analysis due to missing data on key variables, leaving a final sample of $n=484$.

The polling procedure used a random telephone sample obtained from the Office of Admissions and Records that included local telephone numbers but excluded names. The sample obtained for the study is comparable to the population of the students enrolled in the same semester for gender and race. However, the age and academic class distributions are skewed, with the sample over-representing freshman (44\% in the sample compared to $17 \%$ universitywide). This may be due to the restriction of the sample to younger students as well as freshmen's greater likelihood of living in campus dormitories $(62.8 \%$ of the total sample lived in the dorms).

\section{Dependent Variable}

The dependent variable, a measure of students' anticipated policy violations, comprises six items measuring specific offense categories. Students were asked to indicate the extent 
to which they agreed or disagreed with the following statements about their subsequent behavior. All six items reflect actions that are expressly prohibited in the new policy, and are taken from the actual text of the policy, which was being widely circulated around the time the survey was conducted. The interview process provided a degree of context in which to consider future alcohol-related behaviors by (1) briefing respondents that they would be answering questions about the new campus alcohol policy, and (2) asking respondents questions about their more general alcohol-related behaviors, such as frequency and whether their friends drink (included as controls, see below), prior to the questions about anticipated policy violation.

1. "I will possess alcohol on campus."

2. "I will provide alcohol to underage acquaintances."

3. "I will host a party on campus where alcohol is served."

4. "I will get drunk on campus."

5. "I will drive while drunk."

6. "I will attend a campus party on Thursday where alcohol is available."

Students answered each question with a 5-point Likert scale (strongly agree, agree, neither agree nor disagree, disagree, strongly disagree), with items coded so that higher values indicated a greater level of expected future policy violation. A reliability analysis clearly indicated a single factor underlying the six items, with a Cronbach's alpha of .823 for the linear composite. However, the analysis also revealed that reliability could be slightly improved, to an alpha of .840 , by removing the fifth item, "I will drive while drunk." This question, which measures a behavior that is perhaps difficult for respondents to admit, or not easily associated with other campus alcohol violations, was therefore not included in the scale. The sum of the standardized scores on the remaining five items comprise the dependent variable, Anticipated Policy Violation (APV).

\section{Theoretical Variables}

We include two items from deterrence theory, each of which refers to the new alcohol policy's potential future 
deterrent effects on students through informal sanctions. Respondents answered each question on the same 5-point Likert scale as the dependent variable, indicating the extent of their agreement or disagreement with statements expressing anticipated Shame ("Generally, I would feel guilty if I violated the alcohol policy") and Embarrassment ("The people whose opinions I value would lose respect for me if I violated the alcohol policy"). Each of the two items was coded so that a higher value (more agreement with the statement) indicated a greater level of expected deterrence.

We include three variables measuring religiosity, each corresponding to one of three respective questions to which respondents indicate their level of agreement or disagreement via the 5-point Likert scale. The first variable, Salience, reflects respondents' level of "religious identity salience" (Wimberley 1989), measured by level of agreement with the statement "Religion is a very important part of my life." The second variable, Literalness, uses the statement "I believe the Bible is the literal word of God." According to Grasmick et al. (1991b), a literal interpretation of the Bible is closely associated with more fundamentalist and evangelical protestants, and is tied to stricter moral beliefs. Finally, the third variable, Sinfulness, assesses respondents' fundamentally religious attitude toward alcohol with the statement "Problem drinkers are sinning against God." All three religiosity variables are coded so that higher scores indicated greater agreement with the statements.

Noticeably absent from the religiosity measures is denomination, which the survey unfortunately did not collect. However, the state in which the university is centrally located is itself overwhelmingly comprised of Christian denominations, with 14\% non-affiliated and less than 1\% Jews and Muslims (Kosmin et al. 2001). ${ }^{1}$ The university's undergraduate population is comprised of $75 \%$ in-state students. Only $3 \%$ of

\footnotetext{
${ }^{1}$ These are the most recent state-level denomination indicators that include figures for Jews and Muslims. A 2004 Gallup poll, which similarly indicated less than one-half percent for Jews, did not count Muslims.
} 
undergraduates are international, and while out-of-state students may be somewhat more representative of religious diversity, many are from culturally similar, neighboring states. Overall, we believe that the proportion of non-Christian affiliations added to the undergraduate student population by out-of-state and international students is likely very small. Thus, we must acknowledge that the paucity of non-Christian religions in the sample presents an important limitation, but one that has been accepted in similar studies of religion and deterrence (Grasmick et al. 1991a, 1991b) and that we believe does not invalidate the general theoretical implications of the results.

\section{Control Variables}

Control variables included respondent's basic demographic characteristics, measures of college lifestyle and attitude toward drinking in college, and measures of actual and vicarious drinking experience. Demographic characteristics include age, gender, race, marital status, and socioeconomic status (SES). Age is treated as an interval-ratio variable. Gender, race, and marital status are dummy variables with male, white, and married respondents coded 1. Respondents' SES is measured using father's highest degree of education on a 5-point ordinal scale from "some high school" to "graduate school" (see Table 1).

Five variables measure students' lifestyle. Membership in Greek organizations (Greek), residence in the campus dormitories (Dormitory), and having ever been arrested (Arrested) are dummy variables with positive responses coded 1 . Approximate number of weekly hours spent studying (Study Hours) is an interval/ratio variable, while attitude toward drinking in college (Attitude) is measured by asking respondents their level of agreement or disagreement (on the 5-point Likert scale) with the statement "Alcohol is a positive part of the college lifestyle."

Students who have more regular experiences with drinking, and whose close peers drink, may be more likely to anticipate violating policy provisions as a matter of routine activity, and thus may confound the effects of our theoretical framework. In order to control for direct and vicarious drinking behavior, we implemented two questions that measure 


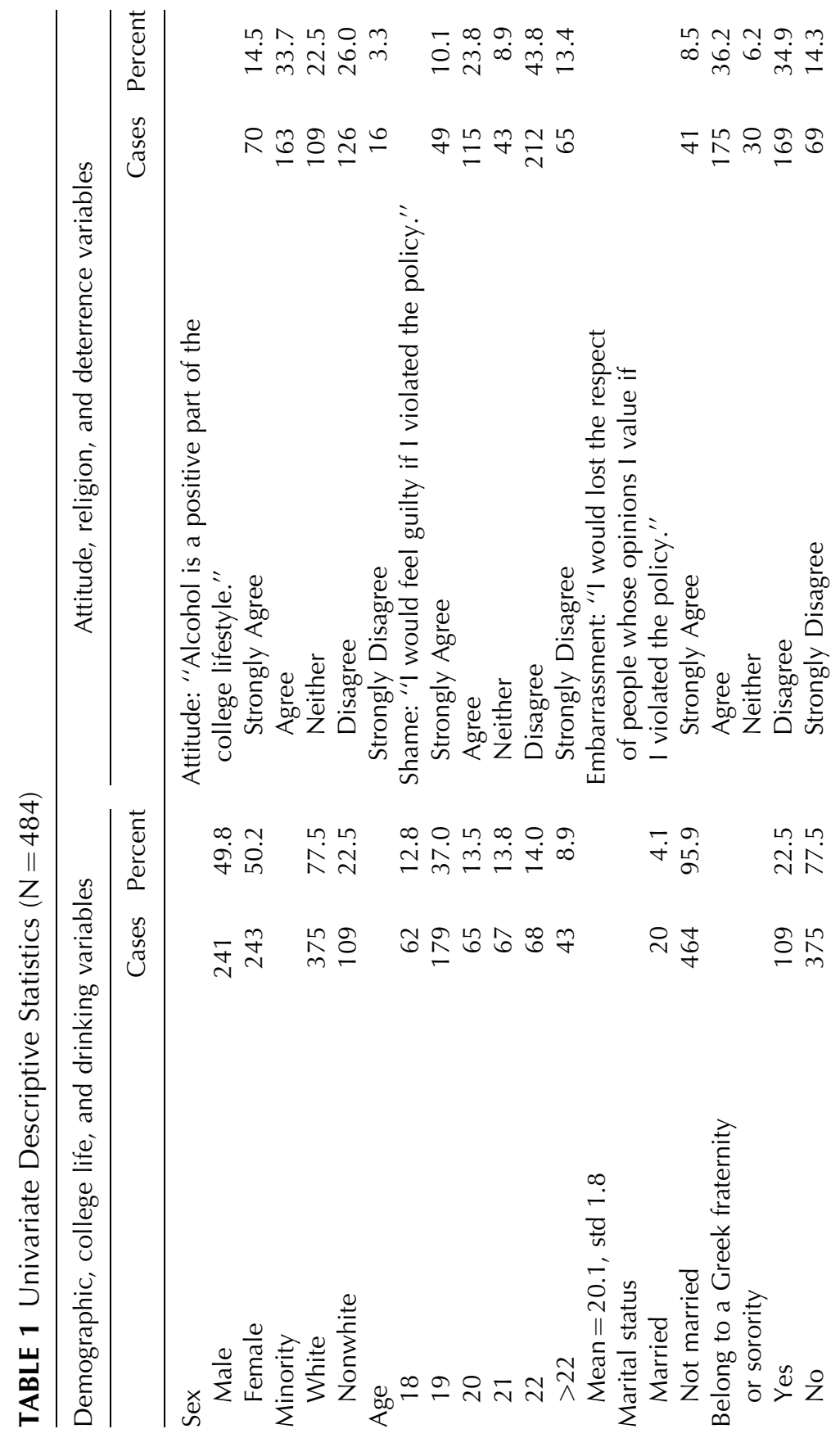




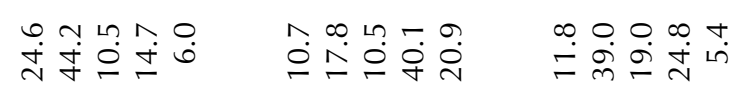

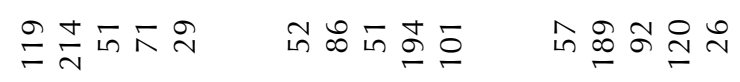
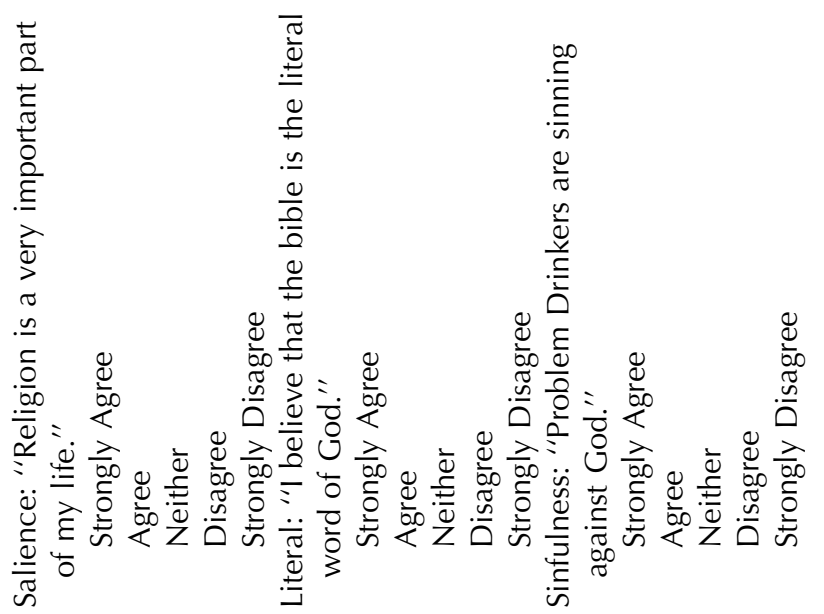

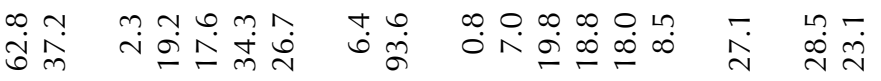
ரீ

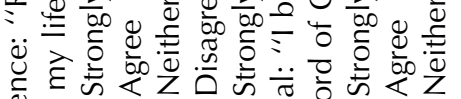
包 $\frac{1}{0}$ . $\stackrel{\frac{\pi}{ \pm}}{=} \sum^{\circ}$

$$
\text { 产 }
$$

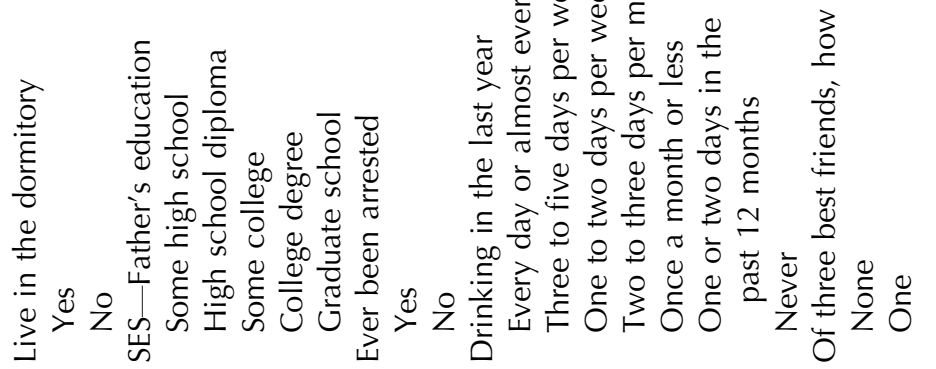

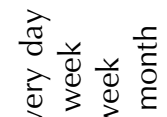

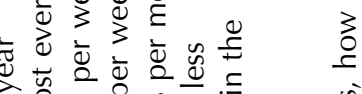

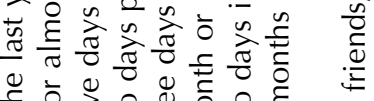

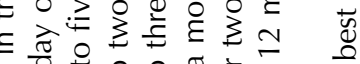

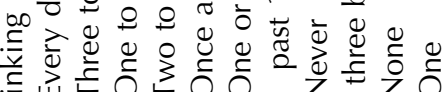




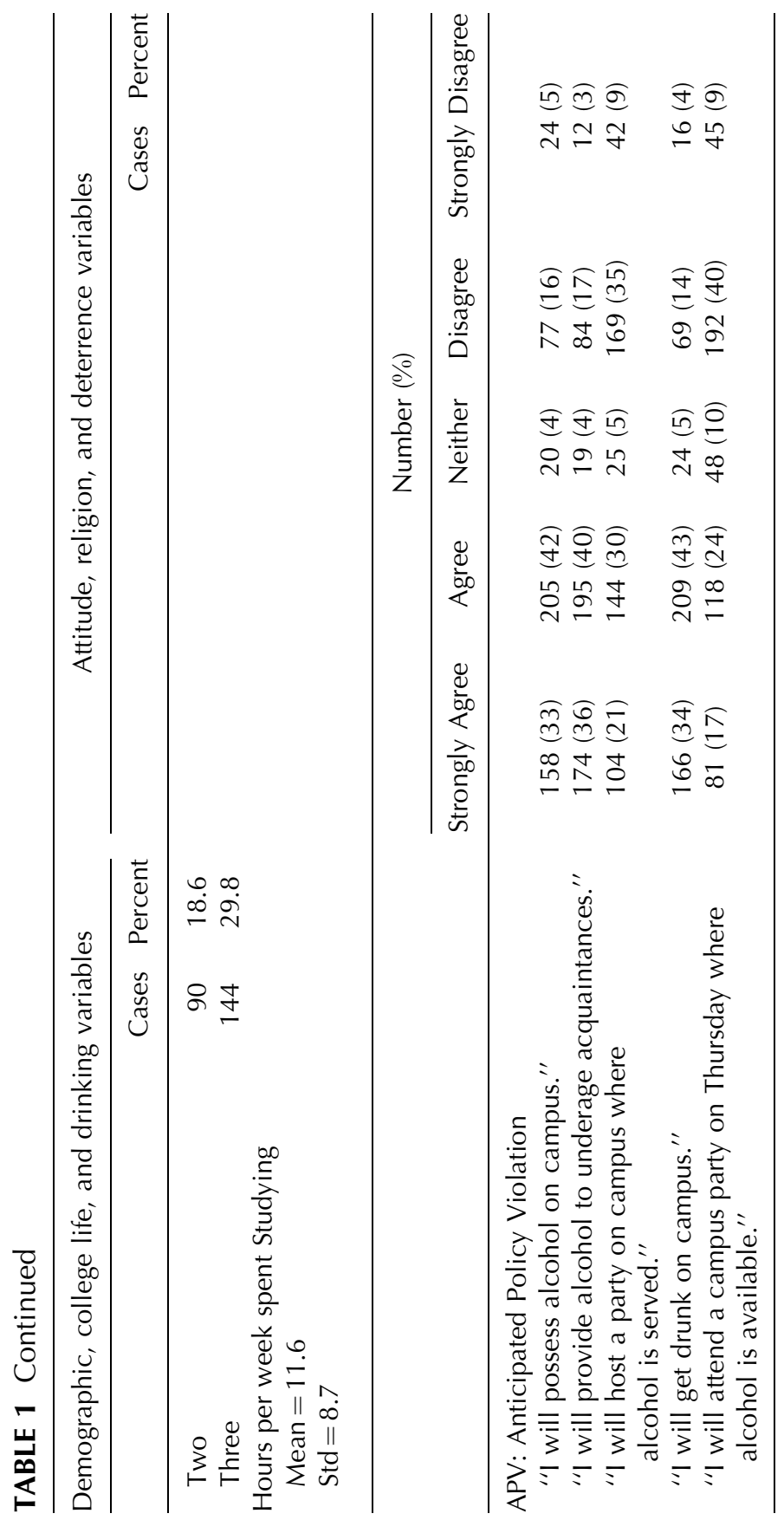


respondents' relative drinking experience. ${ }^{2}$ The first question (Drinking) assessed actual drinking behavior with the question "During the past 12 months, on how many days did you drink alcohol?" Responses were given along a 7-point ordinal scale: never, one or two days in the past twelve months, once a month or less, two or three days a month, one or two days a week, three to five days a week, every day or almost every day. Answers are coded such that higher scores reflected greater frequency of drinking. The second question (Friends) asked respondents "Of your three best friends, how many drink alcohol at least once a week?" with responses on an interval scale.

\section{RESULTS}

Table 1 displays univariate descriptive statistics for each of the theoretical and control variables. The sample was about evenly split by gender, a little over three-quarters were white, and half were under 20 years old. Only 20 students $(4.1 \%)$ were married, while more than a fifth belonged to Greek fraternity or sorority organizations, and nearly two-thirds lived in the college dormitories. More than half had fathers with college degrees, and only 31 of the students $(6.4 \%)$ had ever been arrested. About one-quarter of the sample reported that they had not consumed any alcohol in the past year; among the three-quarters who drank, most did so only a few days per month or less. However, one fifth of the students reported drinking at least one or two days per week, and $81 \%$ had at least one best friend that drank. Finally, about half the students said that they agreed or strongly agreed with the statement that alcohol was a positive part of the college lifestyle.

Participants were broadly distributed on their responses to the deterrence variables. About one-third agree that they would feel shame if they violated the policy, and slightly less than half agree that they would lose the respect of people about whose opinions they cared. Among the religion

\footnotetext{
${ }^{2}$ Our measures of drinking behavior are designed to control for overall likelihood of contact with alcohol and its consumption by both the respondents and their close peers, but are not designed to represent conceptualizations of problem drinking behavior or binge drinking.
} 


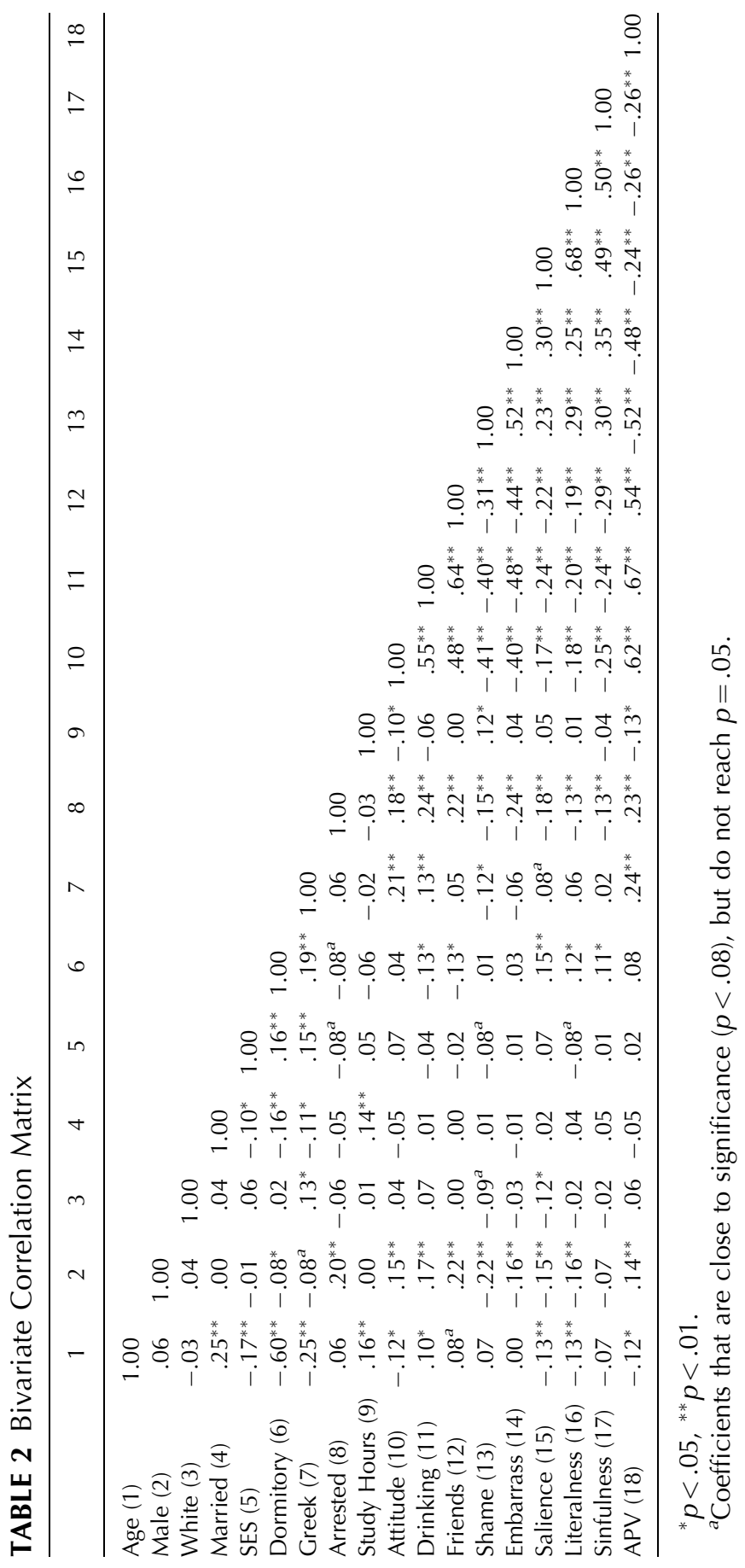


variables, a greater proportion of students agree with the statements that "the bible is the literal word of God" $(28 \%)$ and that "problem drinkers were sinning against God" $(50 \%)$ than agree with the statement that religion was a very important part of their lives $(21 \%)$. This disparity may reflect the extent to which fundamentalist ideologies are prevalent in the Southern-Midwest region, even among college students who do not consider themselves religious.

Table 2 shows the bivariate correlation matrix between all the theoretical and control variables, as well as the dependent measure. Age and gender are the only significant demographic variables that correlated with anticipated policy violation, younger and male respondents being more likely to expect violations. Among lifestyle variables, being in a fraternity or sorority, having ever been arrested, studying fewer hours per week, agreeing that alcohol is a positive part of college life, drinking more frequently and having more friends who drink, are all significantly associated with greater expected violation. Additionally, each of the deterrence and religion measures were individually strong negative predictors of dependent variable.

As bivariate correlates, each of the three religion measures is strongly related to the two deterrence measures. Respondents who are male, had ever been arrested, agreed that alcohol is a positive part of college life, drink more frequently and have more friends who drink, are all more likely to experience embarrassment in association with violating the dry campus policy. While the same variables are also related to the likelihood of experiencing shame, two additional variables correlate with shame that but not embarrassment: belonging to a Greek organization and studying fewer hours per week.

\section{Hypothesis 1}

Table 3 shows the results of an ordinary least squares (OLS) regression to test the hypothesis that social sanctions, as informal deterrents, will reduce the expectation of engaging in prohibited behaviors. OLS coefficients can be readily standardized, which allows for easily interpretable comparisons of effects between variables with different scales. The first model shows that both shame and embarrassment, without 
TABLE 3 OLS Regression Tests of Hypothesis 1. Regression Coefficients (top) and Standardized Coefficients (Bottom) for Anticipated Policy Violation (APV) Regressed on Deterrence Variables and Controls $(\mathrm{N}=484)$

\begin{tabular}{|c|c|c|c|c|c|}
\hline & & Model 1 & Model 2 & Model 3 & Model 4 \\
\hline & Intercept & ***6.492 & ${ }^{* * *} 10.567$ & -0.127 & -0.804 \\
\hline & & 0 & 0 & 0 & 0 \\
\hline \multirow{4}{*}{$\begin{array}{r}\text { Deterrence } \\
\text { variables }\end{array}$} & Shame & $* * *-1.152$ & $* * *-1.116$ & ${ }^{* * *}-0.723$ & $* * *-0.624$ \\
\hline & & -0.367 & -0.356 & -0.230 & -0.199 \\
\hline & Embarrassment & $* * *-0.879$ & $* * *-0.886$ & $* * *-0.506$ & -0.134 \\
\hline & & -0.286 & -0.289 & -0.164 & -0.044 \\
\hline \multirow{10}{*}{$\begin{array}{l}\text { Demo- } \\
\text { graphic } \\
\text { variables }\end{array}$} & Age & & ${ }^{*}-0.203$ & 0.005 & -0.111 \\
\hline & & & -0.095 & 0.002 & -.052 \\
\hline & Male & & 0.151 & -0.040 & -0.203 \\
\hline & & & 0.019 & -0.005 & -0.026 \\
\hline & White & & 0.186 & 0.117 & 0.002 \\
\hline & & & 0.020 & 0.013 & 0.000 \\
\hline & Married & & -0.552 & -0.057 & 0.058 \\
\hline & & & -0.028 & -0.003 & 0.003 \\
\hline & SES & & -0.077 & -0.137 & -0.079 \\
\hline & & & -0.022 & -0.040 & -0.023 \\
\hline \multirow{10}{*}{$\begin{array}{l}\text { College life } \\
\text { and } \\
\text { attitude } \\
\text { variables }\end{array}$} & Greek & & & ${ }^{* *} 0.937$ & ${ }^{*} 0.746$ \\
\hline & & & & 0.100 & 0.080 \\
\hline & Dormitory & & & 0.457 & ${ }^{*} 0.693$ \\
\hline & & & & 0.057 & 0.086 \\
\hline & Arrested & & & ${ }^{*} 1.131$ & .0587 \\
\hline & & & & 0.071 & 0.037 \\
\hline & Study hours & & & -0.019 & -0.018 \\
\hline & & & & -0.043 & -0.041 \\
\hline & Attitude & & & ***1.498 & ${ }^{* * *} 0.833$ \\
\hline & & & & 0.424 & 0.236 \\
\hline \multirow{6}{*}{$\begin{array}{l}\text { Drinking } \\
\text { variables }\end{array}$} & Drinking & & & & ${ }^{* * *} 0.798$ \\
\hline & & & & & 0.347 \\
\hline & Friends & & & & ${ }^{* *} 0.436$ \\
\hline & & & & & 0.133 \\
\hline & $\mathrm{R}^{2}$ & 0.326 & 0.336 & 0.510 & 0.614 \\
\hline & Adjusted $\mathrm{R}^{2}$ & 0.323 & 0.328 & 0.4975 & 0.603 \\
\hline
\end{tabular}

${ }^{*} p<.05,{ }^{* *} p<.01,{ }^{* * *} p<.001$.

control variables, significantly inhibit policy violation, together accounting for $32 \%$ of the variance in the dependent variable. These relationships remain significant when adding demographic and lifestyle variables; however, when 
taking respondents' and their friends' drinking behavior into account, only shame retains its predictive power. The influence of embarrassment is reduced (standardized coefficients of -0.28 to -0.16 , see Table 3 ) when college lifestyle variables are added, then drops below significance when drinking behaviors are also considered.

Thus, hypothesis 1 is partially confirmed. Embarrassment's inhibitive effect on policy violation appears to be a function of lifestyle and drinking behavior. Students who have a favorable attitude about alcohol, who drink and who have friends who drink, are less likely to associate embarrassment with policy violation, and are likewise less likely to anticipate violations. The inhibitive effect of shame on policy violation, however, remains significant, even after controlling for students' attitude and behavior.

\section{Hypothesis 2}

Table 4 shows the results of an OLS regression testing the hypothesis that measures of religiosity affect anticipated policy violation. Without control variables, biblical literalness and the perception of problem drinking as a sin both negatively affect the dependent measure. Religious salience, while a strong negative predictor of anticipated policy violation in a simple bivariate correlation (see Table 2), loses significance when placed in a model with the other dimensions of religiosity. The three measures of religiosity together explain a modest 9\% of the variance in the dependent variable. Adding demographic variables increases the model's overall predictive power slightly, with little change in the significant effects of liternalness and sinfulness (in fact, the coefficients of both these variables increase in the model when demographic controls are included). Adding college lifestyle variables to the model, however, reduces the effect of sinfulness to insignificance, while adding past drinking behavior produces no additional change except a slight increase in the effect of liternalness.

The results partially support the second hypothesis. While all three measures of religiosity independently correlate with anticipated policy violation in simple bivariate relationships, only liternalness and sinfulness remain significantly predictive when all three are considered together, and only 
TABLE 4 OLS Regression Tests of Hypothesis 2. Regression Coefficients (Top) and Standardized Coefficients (Bottom) for Anticipated Policy Violation (APV) Regressed on Religion Variables and Controls $(\mathrm{N}=484)$

\begin{tabular}{|c|c|c|c|c|c|}
\hline & & Model 1 & Model 2 & Model 3 & Model 4 \\
\hline & Intercept & $* * * 3.736$ & ${ }^{* * *} 10.518$ & -1.996 & -1.478 \\
\hline & & 0 & 0 & 0 & 0 \\
\hline \multirow{6}{*}{$\begin{array}{l}\text { Religion } \\
\text { variables }\end{array}$} & Salience & -0.246 & -0.226 & -0.127 & 0.017 \\
\hline & & -0.074 & -0.068 & -0.038 & 0.005 \\
\hline & Literal & ${ }^{*}-0.385$ & ${ }^{*}-0.412$ & ${ }^{*}-0.337$ & ${ }^{* *}-0.376$ \\
\hline & & -0.127 & -0.136 & -0.111 & -0.124 \\
\hline & Sinfulness & $* *-0.555$ & ${ }^{* *}-0.564$ & -0.190 & -0.044 \\
\hline & & -0.159 & -0.162 & -0.054 & -0.013 \\
\hline \multirow{10}{*}{$\begin{array}{l}\text { Demo- } \\
\text { graphic } \\
\text { variables }\end{array}$} & Age & & ${ }^{* *}-0.361$ & -0.049 & ${ }^{*}-0.172$ \\
\hline & & & -0.168 & -0.023 & -0.080 \\
\hline & Male & & ${ }^{*} 0.822$ & 0.221 & -0.058 \\
\hline & & & 0.105 & 0.028 & -0.007 \\
\hline & White & & 0.351 & 0.196 & 0.077 \\
\hline & & & 0.038 & 0.021 & 0.008 \\
\hline & Married & & 0.129 & 0.470 & 0.407 \\
\hline & & & 0.007 & 0.024 & 0.021 \\
\hline & SES & & -0.044 & -0.137 & -0.084 \\
\hline & & & -0.013 & -0.040 & -0.024 \\
\hline \multirow{10}{*}{$\begin{array}{l}\text { College life } \\
\text { and } \\
\text { attitude } \\
\text { variables }\end{array}$} & Greek & & & **1.156 & **0.895 \\
\hline & & & & 0.124 & 0.096 \\
\hline & Dormitory & & & 0.477 & ${ }^{*} 0.709$ \\
\hline & & & & 0.059 & 0.088 \\
\hline & Arrested & & & $* 1.487$ & 0.626 \\
\hline & & & & 0.093 & 0.039 \\
\hline & Study hours & & & -0.029 & -0.026 \\
\hline & & & & -0.065 & -0.058 \\
\hline & Attitude & & & ***1.861 & $* * * 0.957$ \\
\hline & & & & 0.527 & 0.271 \\
\hline \multirow{6}{*}{$\begin{array}{l}\text { Drinking } \\
\text { variables }\end{array}$} & Drinking & & & & ${ }^{* * *} 0.904$ \\
\hline & & & & & 0.393 \\
\hline & Friends & & & & ${ }^{* *} 0.459$ \\
\hline & & & & & 0.140 \\
\hline & $\mathrm{R}^{2}$ & 0.091 & 0.130 & 0.449 & 0.593 \\
\hline & Adjusted $\mathrm{R}^{2}$ & 0.086 & 0.115 & 0.434 & 0.580 \\
\hline
\end{tabular}

${ }^{*} p<.05,{ }^{* *} p<.01,{ }^{* * *} p<.001$ (study hours in model 3 has $p=.066$ ).

literalness retains its predictive power when students' lifestyle and behavior are taken into account. We also hypothesized that the two fundamentalist measures of religiosity 
(literalness and sinfulness) would have stronger negative relationships with the anticipated policy violation than would religious salience. The results are in accord with our prediction, but not in the way expected. Having a literal interpretation of the bible is the only significant predictor of the dependent variable after demographic, lifestyle, and behavioral controls are in place.

\section{Hypothesis 3}

Tables 5 and 6 show the results of OLS analyses in which shame and embarrassment are regressed on the three religiosity measures. In none of the models is religious salience related to shame. Religious salience does positively predict embarrassment, but drops just over the threshold $(p=.0658)$ after drinking behaviors are considered. Biblical literalness and believing that problem drinking is a sin increase the likelihood of shame in all the models, while only the latter remains a significant positive predictor of embarrassment. The explanatory power of religiosity variables is slightly greater for predicting embarrassment (model $\mathrm{E} 1, \quad \mathrm{R}^{2}=.145$ ) than for predicting shame (model S1, $\mathrm{R}^{2^{\prime}}=.115 \%$ ), and in both cases the consideration of control variables, especially attitude and drinking behavior, reduces the influence of all the religiosity measures. After all control variables are included, the hypothesis is only confirmed for (1) the effect of biblical literalness on increasing the likelihood of shame and (2) the effect of believing that problem drinking is a sin on increasing the likelihood of both shame and embarrassment.

\section{Hypothesis 4}

Table 7 shows the results of OLS models with anticipated policy violation regressed on both religiosity and deterrence variables. In model 4, with all control variables, only one deterrence variable and one religiosity variable retain significance. Contrary to the hypothesis, the one religiosity variable that predicts the dependent variable in the complete model, biblical literalness, is not a significant predictor until respondents' drinking behavior (frequency of drinking and number of friends who drink) is taken into account. Furthermore, embarrassment loses the strong influence on anticipated policy violation that it had in each of 
TABLE 5 OLS Regression Tests of Hypothesis 3. Regression Coefficients (Top) and Standardized Coefficients (Bottom) for Shame Regressed on Religion Variables and Controls $(\mathrm{N}=484)$

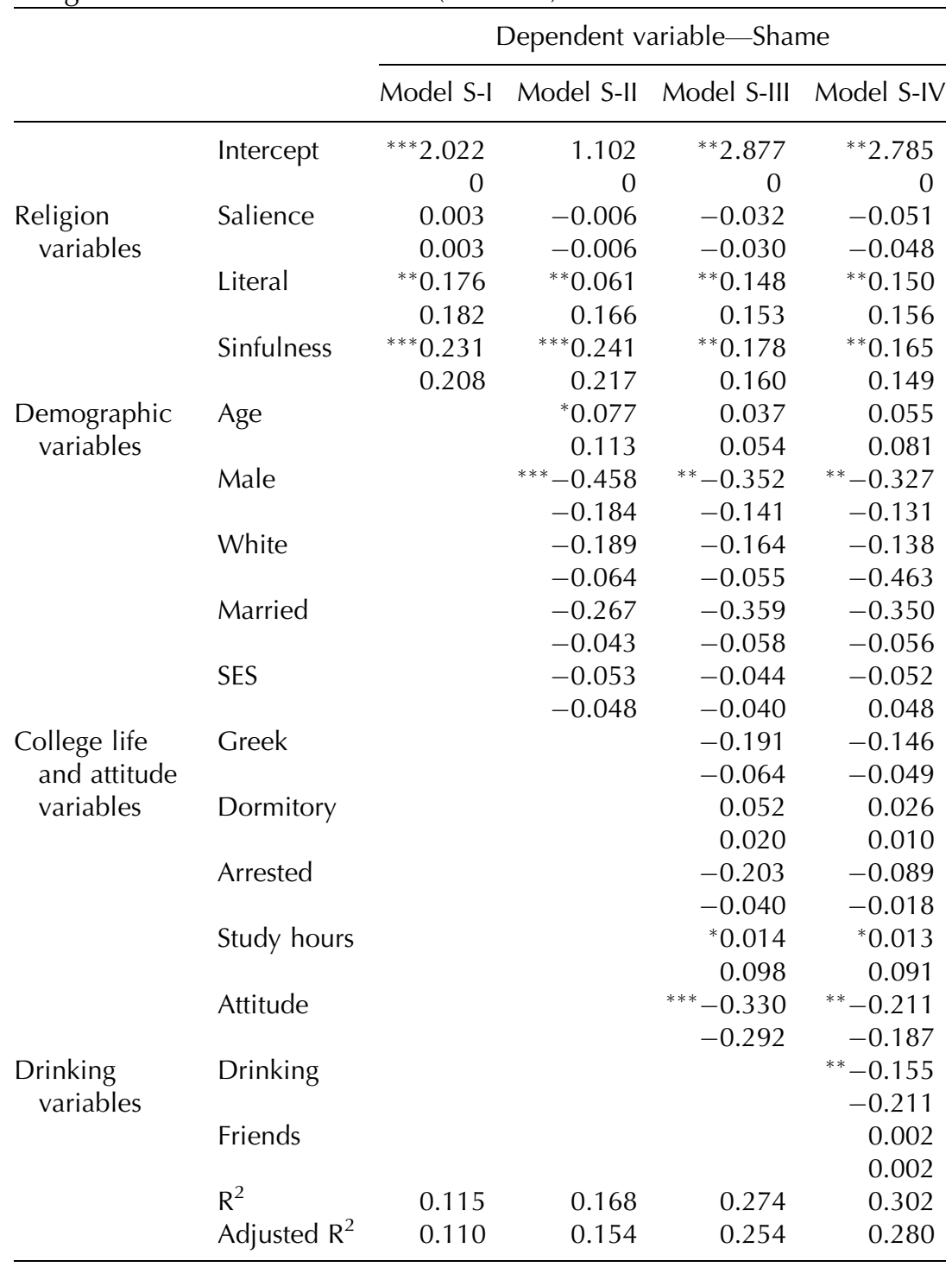

${ }^{*} p<.05,{ }^{* *} p<.01,{ }^{* * *} p<.001$. 
TABLE 6 OLS Regression Tests of Hypothesis 3. Regression Coefficients (Top) and Standardized Coefficients (Bottom) for Embarrassment Regressed on Religion Variables and Controls $(\mathrm{N}=484)$

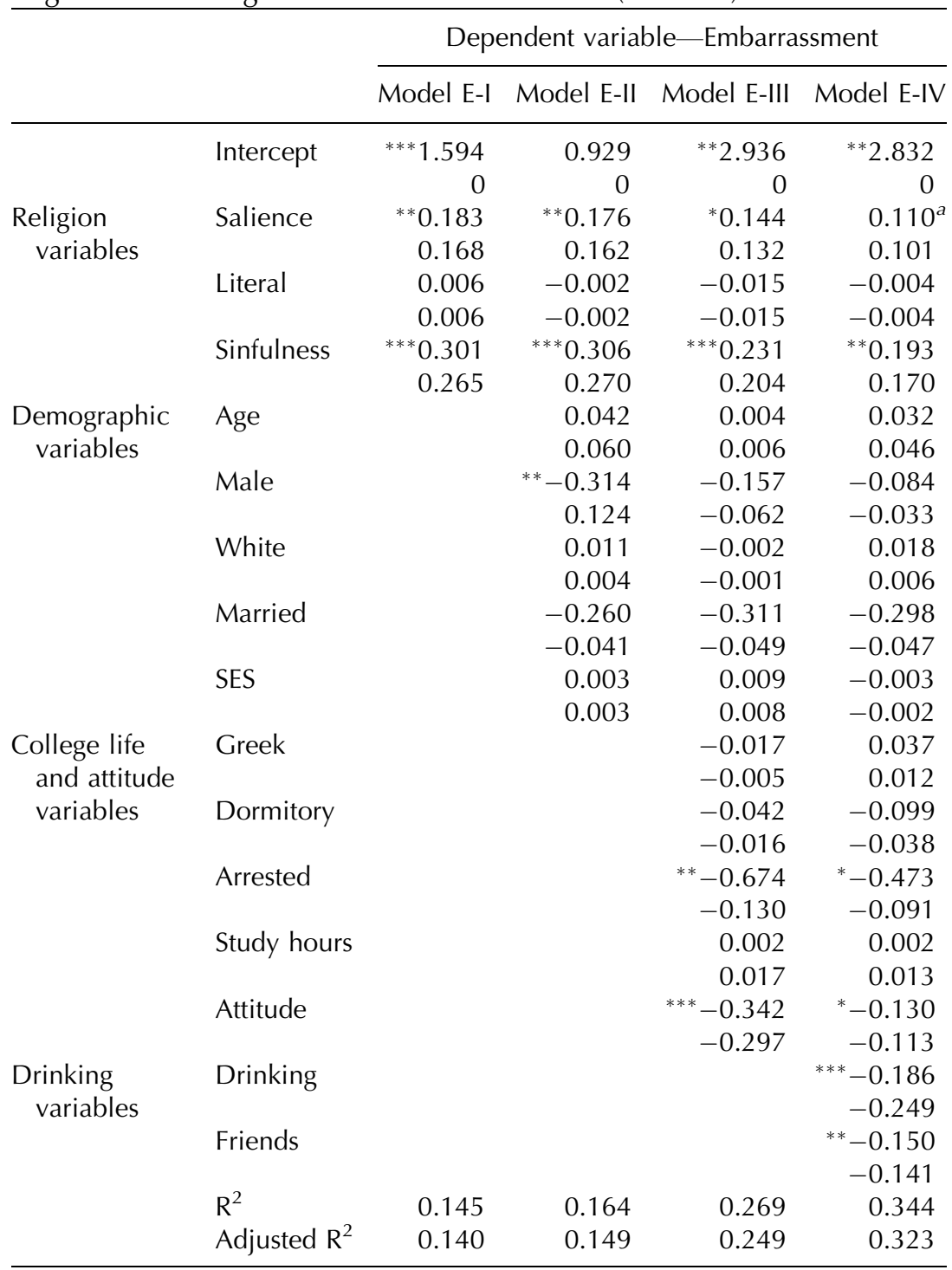

${ }^{*} p<.05,{ }^{* *} p<.01,{ }^{* * *} p<.001$.

${ }^{a}$ Salience missed significant prediction of embarrassment by a slight margin, $p=.0658$. 
TABLE 7 OLS Regression Tests of Hypothesis 4. Regression Coefficients (Top) and Standardized Coefficients (Bottom) for Anticipated Policy Violation (APV) Regressed on Deterrence Variables, Religion Variables, and Controls $(\mathrm{N}=484)$

\begin{tabular}{|c|c|c|c|c|c|}
\hline & & Model 1 & Model 2 & Model 3 & Model 4 \\
\hline \multirow{6}{*}{$\begin{array}{r}\text { Deterrence } \\
\text { variables }\end{array}$} & \multirow[t]{2}{*}{ Intercept } & $* * * 7.251$ & $* * * 12.431$ & 1.323 & 0.459 \\
\hline & & 0 & 0 & 0 & 0 \\
\hline & \multirow[t]{2}{*}{ Shame } & ${ }^{* * *}-1.094$ & $* * *-1.047$ & $* * *-0.673$ & $* * *-0.577$ \\
\hline & & -0.349 & -0.334 & -0.215 & -0.184 \\
\hline & \multirow[t]{2}{*}{ Embarrassment } & $* * *-0.817$ & $* * *-0.818$ & ${ }^{* *}-0.471$ & -0.117 \\
\hline & & -0.266 & -0.266 & -0.153 & -0.038 \\
\hline \multirow{6}{*}{$\begin{array}{l}\text { Religion } \\
\text { variables }\end{array}$} & \multirow[t]{2}{*}{ Salience } & -0.094 & -0.089 & -0.081 & 0.001 \\
\hline & & -0.028 & -0.027 & -0.024 & 0.000 \\
\hline & \multirow[t]{2}{*}{ Literal } & -0.188 & -0.245 & -0.245 & $*-0.290$ \\
\hline & & -0.062 & -0.081 & -0.081 & -0.096 \\
\hline & \multirow[t]{2}{*}{ Sinfulness } & -0.056 & -0.062 & 0.039 & 0.074 \\
\hline & & -0.016 & -0.018 & 0.011 & 0.021 \\
\hline \multirow{10}{*}{$\begin{array}{l}\text { Demographic } \\
\text { variables }\end{array}$} & \multirow[t]{2}{*}{ Age } & & $* *-0.245$ & -0.022 & -0.134 \\
\hline & & & -0.114 & -0.010 & -0.064 \\
\hline & \multirow[t]{2}{*}{ Male } & & 0.086 & -0.090 & -0.256 \\
\hline & & & 0.011 & -0.012 & -0.033 \\
\hline & \multirow[t]{2}{*}{ White } & & 0.161 & 0.085 & 0.000 \\
\hline & & & 0.017 & 0.009 & 0.000 \\
\hline & \multirow[t]{2}{*}{ Married } & & -0.363 & 0.081 & 0.171 \\
\hline & & & -0.019 & 0.004 & 0.009 \\
\hline & \multirow[t]{2}{*}{ SES } & & -0.096 & -0.162 & -0.114 \\
\hline & & & -0.028 & -0.047 & -0.033 \\
\hline \multirow{10}{*}{$\begin{array}{l}\text { College life } \\
\text { and attitude } \\
\text { variables }\end{array}$} & \multirow[t]{2}{*}{ Greek } & & & $* * 1.019$ & ${ }^{* *} 0.815$ \\
\hline & & & & 0.109 & 0.087 \\
\hline & \multirow[t]{2}{*}{ Dormitory } & & & 0.492 & ${ }^{*} 0.712$ \\
\hline & & & & 0.061 & 0.088 \\
\hline & \multirow[t]{2}{*}{ Arrested } & & & 1.033 & 0.520 \\
\hline & & & & 0.065 & 0.033 \\
\hline & \multirow[t]{2}{*}{ Study hours } & & & -0.019 & -0.018 \\
\hline & & & & -0.042 & -0.040 \\
\hline & \multirow[t]{2}{*}{ Attitude } & & & $* * * 1.478$ & ${ }^{* * *} 0.820$ \\
\hline & & & & 0.418 & 0.232 \\
\hline \multirow{6}{*}{$\begin{array}{l}\text { Drinking } \\
\text { variables }\end{array}$} & \multirow[t]{2}{*}{ Drinking } & & & & ${ }^{* * *} 0.793$ \\
\hline & & & & & 0.345 \\
\hline & \multirow[t]{2}{*}{ Friends } & & & & ${ }^{* *} 0.442$ \\
\hline & & & & & 0.135 \\
\hline & $\mathrm{R}^{2}$ & 0.334 & 0.348 & 0.518 & 0.621 \\
\hline & Adjusted $\mathrm{R}^{2}$ & 0.327 & 0.334 & 0.502 & 0.607 \\
\hline
\end{tabular}




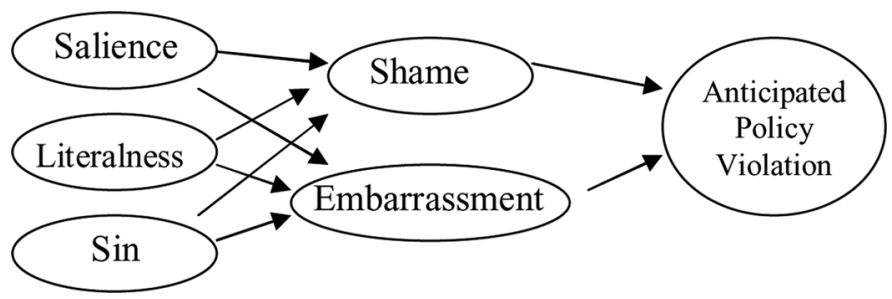

FIGURE 1 Graphical Illustration of Hypothesis 4.

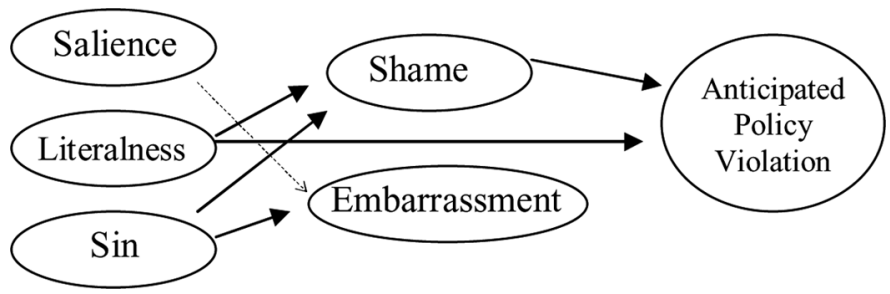

FIGURE 2 Graphical Illustration of Results for Hypotheses 3 and 4.

the previous models, falling below significance when drinking behavior is added.

The diagram in Figure 1 illustrates the conceptual framework proposed in hypotheses 3 and 4, while the diagram in Figure 2 illustrates the actual relationships found when we tested these hypotheses. Religiosity measures, as expected, contribute toward reducing anticipated policy violation through the intervening deterrence variables, but this is the case only with shame and not with embarrassment. While religious salience and believing that problem drinking is a sin lose their direct effects on the dependent variable, biblical literalness unexpectedly regains its negative direct effect after controlling for students' past drinking behavior.

\section{DISCUSSION}

Our most basic finding is that religiosity reduces the likelihood of anticipating delinquent behavior, even when age, gender, and SES are taken into account. This result supports past research reviewed earlier in this paper and contributes toward validating the use of projected offending as a 
dependent measure. Unique to the present study is the finding that fundamentalist measures of religiosity (biblical literalness and belief in the sinfulness of problem drinking) eclipse general religious salience when considered together. Furthermore, the present findings show that religiosity tends to increase the likelihood of experiencing informal social deterrence. Religious students were more likely to anticipate the social sanction of embarrassment, which inhibited projected delinquency until drinking behavior was considered, as well as the internal sanction of shame, which inhibited projected delinquency in all the models.

The analysis in our study affirms the importance of informal sanctions as a pathway through which religiosity insulates against delinquent behavior. Religiosity tends to increase the likelihood of informal sanctions, which in turn tends to decrease the likelihood of projected offending. However, our results present an unexpected caveat. Consistent with Grasmick et al.'s (1991a) framework for explaining religiosity and informal sanctions in regulating tax-cheating behavior in adults, we predicted that informal sanctions would fully account for the effect of religiosity on projected offending. However, one of the fundamentalist measures, biblical literalness, remains significant even after accounting for all other measures (see Table 7 and Figure 2). Believing in biblical literalness appears to inhibit projected offending regardless of lifestyle, attitude, current behavior, or the likelihood of experiencing informal sanctions. Additionally, while the social sanction of embarrassment substantially inhibited projected offending in the bivariate relationship and remained significant when age, gender, SES, and lifestyle/ attitude were considered, this relationship was accounted for by current behavior, including drinking and having friends who drink. Only the internal sanction of shame remained a significant inhibitor to projected offending.

Consider the illustration in Figure 2, which diagrammatically summarizes the results of the regression analyses. Respondents who were more fundamentalist in their religiosity, as measured by biblical literalness and belief in problem drinking as sinful, were more likely to anticipate feeling shame, controlling for college lifestyle, attitude, and drinking behavior. In turn, shame predicted anticipated avoidance of policy violations, controlling for lifestyle, attitude, drinking, 
and all religiosity measures. In contrast, embarrassment's inhibitive effect on policy violation appears to be a function of lifestyle and drinking behavior, including the social context of having friends who drink, and who presumably approve of drinking. Not surprisingly, students who have a favorable attitude about alcohol, who drink and who have friends who drink, are less likely to associate embarrassment with policy violation, and are likewise less likely to anticipate violations.

The inhibitive effect of shame on policy violation, however, is robust to these other influences, and so is fundamentalist religiosity, which appears to provide some of the socialization necessary to develop informal sanctions. Although more fundamentally religious students were substantially less likely to drink, have friends who drink, or have favorable attitudes toward alcohol in college, the reason that more fundamentally religious students anticipated less policy violation was not simply their aversion to alcohol, since shame and biblical literalness maintained their importance (in fact, biblical literalness increased its importance) after controlling for lifestyle, attitude, and drinking. Considered together, we might summarize the results regarding both religiosity and informal sanctions as suggesting that (1) while religiosity reduces the likelihood of projected offending, fundamentalist religiosity does so more strongly, and the latter accounts for the effect of general religious salience when considered together, (2) religiosity affects projected offending at least partly through informal deterrence, and (3) the internal sanction of shame is more robust to lifestyle, attitude, and behavioral variation, and is a stronger inhibitor of anticipated delinquency, than the social sanction of embarrassment.

\section{Policy Implications}

Since shame was the best predictor of lowering anticipated policy violation, remaining strong even after accounting for lifestyle, attitude, and drinking behaviors, exploring the use of reintegrative shaming techniques in the development of campus alcohol programs may be a useful step for universities that are currently implementing restrictive alcohol policies. Reintegrative shaming is a perspective that seeks to provide restorative justice for criminal and delinquent 
offenders by fostering genuine remorse and the socially reintegrating the offender back into the normative social environment (Braithwaite 1989, 1995). Alcohol bans will certainly elicit resistance in a population that strongly incorporates drinking into its normative structure (nearly half of the students believed that alcohol was a positive part of the college lifestyle). However, some success may be possible if campus-community partnerships can help socially integrate students to accept responsible drinking norms. Anecdotal evidence suggested that students believed the policy to be designed for the protection of the university and not the students. A restorative justice perspective on future campus alcohol policy would be wise to focus on inclusiveness between students, community, and administration.

\section{Limitations and Directions for Future Research}

Beyond the realm of college drinking behavior, the results imply that social norms that are strongly internalized, such as the fundamentalist measures of religiosity, may be insulating against criminal and delinquent behavior, and that internal sanctions may be more powerful than social sanctions, especially when the likelihood of embarrassment is thwarted by social lifestyle (in this case, drinking and having friends who drink). The venues of criminality and delinquency in which this framework have been considered in past research reviewed earlier in this article (drunk driving, cheating on taxes) should be expanded in order to triangulate between behaviors that vary in severity and social disapproval. The present study was unique in that it used college students, ${ }^{3}$ and that it involved an ascetically proscribed behavior that may not be as clearly condemned in larger society as drunk driving and tax evasion (Grasmick et al. 1991a; Grasmick et al. 1999).

However, extending the inquiry to include many of the common forms of delinquency measured in self-reports (using illicit drugs, academic cheating, larceny

\footnotetext{
${ }^{3}$ Most of the survey participants were still young enough, and living in enough of a pre-adulthood socioeconomic context, to be considered "adolescents." Thus, we believe that the term delinquency rather than criminality is appropriate to refer to their violation of school alcohol regulations.
} 
and shoplifting, vandalism, truancy) as well as comparing between projected offending and past offending, would help to strengthen and expand the findings. Additionally, a comparison of the importance of informal relative to formal sanctions would constitute an important expansion of questions tested in this study, which were limited to informal sanctions.

Also, the survey used in the present survey was not originally conducted with religiosity strongly in mind, and thus did not include a measure of religious participation or (as discussed earlier) denomination. The stronger finding for internal sanctions (shame) than social sanctions (embarrassment) may be examined more thoroughly if a measure of religiosity were used that specifically considered the socially integrative aspects of religion. Overall, expanding the use of alternative measurements, including the use of (1) adults and adolescents, (2) different types of criminal and delinquent behavior, (3) projected and past offending, and (4) varying measures of religiosity and control mechanisms, will enhance the extent to which future researchers can address new studies of religiosity and deterrence.

\section{REFERENCES}

Akers, Ronald. 1990. "Rational Choice, Deterrence, and Social Learning Theory in Criminology: The Path Not Taken." Journal of Criminal Law and Criminology 81(3):653-676.

Beccaria, Cesare. [1775] 1963. On Crime and Punishments. Translated with an introduction by Henry Paolucci. New York: McMillan Publishing Co.

Bentham, Jeremy. [1789] 1970. An Introduction to the Principles of Morals and Legislation. London: The Athlone Press.

Bohm, R. M. 1997. A Primer on Crime and Delinquency. Belmont, CA: Wadsworth.

Braithwaite, John. 1989. Crime, Shame, and Reintegration. Cambridge: Cambridge University Press.

Braithwaite, John. 1995. "Reintegrative Shaming, Republicanism, and Policy." Pp. 191-204 in Crime and Public Policy: Putting Theory to Work, edited by Hugh Barlow. Boulder, CO: Westview Press.

Burden, J. L. and S. A. Maisto. 2000. "Expectancies, Evaluations and Attitudes: Prediction of College Student Drinking Behavior." Journal of Studies on Alcohol 61:323-331. 
Burkett, Steven R. and Mervin White. 1974. "Hellfire and Delinquency: Another Look." Journal for the Scientific Study of Religion 13(4):455-462.

Burkett, Steven R. and David A. Ward. 1993. "A Note on Perceptual Deterrence, Religiously Based Moral Condemnation, and Social Control." Criminology 31(1):119-134.

Chaloupka, F. J. and H. Weschler. 1996. "Binge Drinking in College: The Impact of Price, Availability, and Alcohol Control Policies." Contemporary Economic Policy 14:112-124.

Cochran, John K. 1988. "The Effect of Religiosity on Secular and Ascetic Deviance." Sociological Focus 21(4):293-306.

Clapp, J. D., M. Johnson, R. B. Voas, J. E. Lange, A. Shillington, and C. Russell. 2005. "Reducing DUI among US College Students: Results of an Environmental Prevention Trial." Addiction 100: 327-334.

Clapp, J. D., J. Lange, J. W. Min, A. Shillington, M. Johnson, and R. Voas. 2003. "Two Studies Examining Environmental Predictors of Heavy Drinking by College Students." Prevention Science 4(2):99-108.

Donovan, J. E., R. Jessor, and F. M. Costa. 1999. "Adolescent Problem Drinking: Stability of Psychosocial and Behavioral Correlates across a Generation." Journal of Studies on Alcohol 60(3):352-361.

Durkheim, Emile. [1912] 1947. The Elementary Forms of Religious Life, trans. Joseph Swain. Glencoe, IL: Free Press.

Foglia, Wanda D. 1997. "Perceptual Deterrence and the Mediating Effect of Internalized Norms among Inner-City Teenagers." Journal of Research in Crime and Delinquency 34(4):414-442.

Garland, David. 1990. Punishment and Modern Society. Chicago: University of Chicago Press.

Geerken, M. R. and W. R. Gove. 1975. "Deterrence: Some Theoretical Considerations." Law and Society Review 9(3):497-513.

Gibbs, Jack P. 1975. Crime, Punishment, and Deterrence. New York: Elsevier.

Grasmick, Harold G. and Donald E. Green. 1981a. "Deterrence and the Morally Committed." The Sociological Quarterly 22(Winter): $1-14$.

1981b. "Legal Punishment, Social Disapproval and Internalization as Inhibitors of Illegal Behavior." The Journal of Law and Criminology 71(1):325-335.

Grasmick, Harold G., Elizabeth Davenport, Mitchell B. Chamlin, and Robert J. Bursik, Jr. 1992. "Protestant Fundamentalism and the Retributive Doctrine of Punishment." Criminology 30(1):21-45.

Grasmick, Harold G., Robert J. Bursik, Jr., and Bruce J. Arneklev. 1999. "Reduction in Drunk Driving as a Response to Increased Threats of Shame, Embarrassment, and Legal Sanctions." Criminology 31(1):41-67. 
Grasmick, Harold G., Robert J. Bursik Jr., and John K. Cochran. 1991a. "Render unto Caesar What is Caesar's": Religiosity and Taxpayers' Inclination to Cheat." Sociological Quarterly 32(2):251-266.

Grasmick, Harold G., Karyl Kinsey, and John K. Cochran. 1991b. "Denomination, Religiosity and Compliance with the Law: A Study of Adults." Journal for the Scientific Study of Religion 30(1):99-107.

Hirschi, Travis and Rodney Stark. 1969. "Hellfire and Delinquency." Social Problems 17(2):202-213.

Inciardi, J. A. 2002. The War on Drugs III: The Continuing Saga of the Mysteries and Miseries of Intoxication, Addiction, Crime, and Public Policy. Boston, MA: Allyn and Bacon.

Kelley, Margaret S., Miyuki Fukushima, Andrew L. Spivak, and David Payne. 2009. "Deterrence Theory and the Role of Shame in Projected Offending of College Students Against a Ban on Alcohol." Journal of Drug Education 39(4):419-437.

Klepper, S. and D. Nagin. 1989. "The Deterrent Effect of Perceived Certainty and Severity of Punishment Revisited." Criminology 27(4):721-746.

Kosmin, Barry A., Egon Mayer, and Ariela Keysar. 2001. American Religious Identification Survey. New York: The Graduate Center of the City University of New York. Available at (http://www.gc.cuny. edu/faculty/research_briefs/aris.pdf) (accessed September 7, 2009).

Kuo, M., H. Wechsler, P. Greenberg, and H. Lee. 2003. "The Marketing of Alcohol to College Students: The Role of Low Prices and Special Promotions." American Journal of Preventive Medicine 25(3):204-211.

Lange, J. E., J. D. Clapp, R. Turrisi, R. Reavy, J. Jaccard, and M. B. Johnson. 2002. "College Binge Drinking: What Is It? Who Does It?" Alcoholism: Clinical and Experimental Research 26(5):723-730.

Lanza-Kaduce, L. 1988. "Perceptual Deterrence and Drinking and Driving among College Students." Criminology 26(2):321-341.

Liska, A. E. and S. F. Messner. 1999. Perspectives on Crime and Deviance (3rd ed.) Upper Saddle River, NJ: Prentice Hall.

Middleton, Russell and Snell Putney. 1962. "Religion, Normative Standards, and Behavior." Sociometry 25:145-152.

Mills, K. C., B. Pfaffenberger, and D. McCarty. 1981. "Guidelines for Alcohol Abuse Prevention on the College Campus." Journal of Higher Education 52(4):399-414.

Mooney, L. A. and R. Gramling. 1993. "The Differential Effects of the Minimum Drinking Age Law." Sociological Inquiry 63(3):330-338.

Nagin, D. S. and G. Pogarsky. 2001. "Integrating Celerity, Impulsivity, and Extralegal Sanction Threats into a Model of General Deterrence: Theory and Evidence." Criminology 39(4):865-892.

- 2003. "An Experimental Investigation of Deterrence: Cheating, Self-Serving Bias, and Impulsivity." Criminology 41(1):167-194. 
Paternoster, R. 1987. "The Deterrent Effect of Perceived Certainty and Severity of Punishment: A Review of the Evidence and Issues." Justice Quarterly 4:173-217.

Pogarsky, G. 2004. "Projected Offending and Contemporaneous Rule-Violation: Implications for Heterotypic Continuity." Criminology 42(1):111-135.

Pratt, Travis C., Francis T. Cullen, Kristie R. Blevins, Leah E. Diagle, and Tamara D. Madensen, eds. 2006. The Empirical Status of Deterrence Theory. New Brunswick, NJ: Transaction.

Shover, N. and D. Honaker. 1992. "The Socially Bounded Decision Making of Persistent Property Offenders." The Howard Journal of Criminal Justice 31: 276-293.

Straus, R. and D. B. Shelden. 1953. Drinking in College. New Haven, CT: Yale University Press.

Tittle, C. R. and R. Paternoster. 2000. Social Deviance and Crime: An Organizational and Theoretical Approach. Los Angeles, CA: Roxbury Publishing Company.

Tittle, Charles R. and Michael R. Welch. 1983. "Religiosity and Deviance: Toward a Contingency Theory of Constraining Effects." Social Forces 61(3):653-682.

Wagenaar, A. C., T. L. Toomey, and D. J. Erickson. 2005. "Preventing Youth Access to Alcohol: Outcomes from a Multi-Community TimeSeries Trial." Addiction 100:335-345.

Wechsler, H., G. W. Dowdall, A. Davenport, and W. DeJong. 1993. Binge Drinking on Campus: Results of a National Study [Bulletin]. Washington, DC: Higher Education Center for Alcohol and Other Drug Prevention, U.S. Department of Education.

Wechsler, H., G. W. Dowdall, G. Maenner, J. Gledhill-Hoyt, and H. Lee. 1998. "Changes in Binge Drinking and Related Problems among American College Students between 1993 and 1997: Results of the Harvard School of Public Health College Alcohol Study." Journal of American College Health 47:57-68.

Wechsler, H., J. E. Lee, J. Gledhill-Hoyt, and T. F. Nelson. 2001. "Alcohol Use and Problems at Colleges Banning Alcohol: Results of National Survey." Journal of Studies on Alcohol 62(2):133-141.

Wechsler, H., J. E. Lee, M. Kuo, and H. Lee. 2000. "College Binge Drinking in the 1990s: A Continuing Problem." Journal of American College Health 48:199-210.

Wechsler, H., M. Seibring, I. Liu, and M. Ahl. 2004. "Colleges Respond to Student Binge Drinking: Reducing Student Demand or Limiting Access." Journal of American College Health 52(4):159-168.

Wechsler, H. L., J. E. Juo, and M. Meichun Seibring. 2002. "Trends in College Binge Drinking during a Period of Increased Prevention Efforts; Findings from 4 Harvard School of Public Health College 
Alcohol Study Surveys: 1993-2001." Journal of American College Health 50(5):203-217.

Weitzman, E. R. and T. F. Nelson. 2004. "College Student Binge Drinking and the 'Prevention Paradox': Implications for Prevention and Harm Reduction." Journal of Drug Education 34(3):247-266.

Williams, J., F. J. Chaloupka, and H. Wechsler. 2005. "Are There Differential Effects of Price and Policy on College Students' Drinking Intensity?" Contemporary Economic Policy 23(1):78-90.

Wolaver, A. M. 2002. "Effects of Heavy Drinking in College on Study Effort, Grade Point Average, and Major Choice." Contemporary Economic Policy 20(4):415-428.

Workman, T. A. 2001. "Pleasure Versus Public Health: Controlling Collegiate Binge Drinking." Pp. 137-144 in Readings in Deviant Behavior (2nd edition), edited by A. Thio and T. C. Calhoun. Boston: Allyn and Bacon.

Zimring, Frank E. and Gordon Hawkins. 1973. Deterrence: The Legal Threat in Crime Control. Chicago: University of Chicago Press. 